Article

\title{
Direct dehydrogenation of isobutane to isobutene over carbon catalysts
}

\author{
Yang Li, Zhongshen Zhang, Junhui Wang, Chunyan Ma, Hongling Yang, Zhengping Hao* \\ Department of Environmental Nano-materials and Technologies, Research Center for Eco-Environmental Sciences, Chinese Academy of Sciences, \\ Beijing 100085, China
}

A R T I C L E I N F O

Article history:

Received 28 February 2015

Accepted 18 May 2015

Published 20 August 2015

\section{Keywords:}

Carbon

Direct dehydrogenation

Isobutane

Isobutene

Heterogeneous catalysis

\begin{abstract}
A B S T R A C T
Various carbon materials were found to function as highly active catalysts for the direct dehydrogenation of isobutane without the addition of oxidizing gases (such as oxygen, carbon dioxide or nitrous oxide) or the deposition of metal particles. Among these materials, coconut shell activated carbon (CSAC) generated the highest isobutane conversion of 70\%. It is notable that the CSAC catalyst exhibited a high degree of catalytic stability that was comparable to that of conventional catalysts and was able to maintain a selectivity for isobutene of approximately $76 \%$. The most important factor with regard to the catalytic activity of both fresh and used carbon catalysts was determined to be the specific surface area of the material. These results are unique since they indicate that various carbon materials, including deposited coke, can behave as effective catalysts for the isobutane conversion reaction even without the presence of functional groups.
\end{abstract}

(C) 2015, Dalian Institute of Chemical Physics, Chinese Academy of Sciences. Published by Elsevier B.V. All rights reserved.

\section{Introduction}

Isobutene is the most versatile chemical intermediate among the $\mathrm{C}_{4}$ olefins, and is an important precursor for the production of oxygenates that are added to reformulated or oxygenated gasoline. Historically, isobutene has been generated using the same thermal and catalytic hydrocracking processes employed for gasoline production [1]. However, because of the growing demand for isobutene, the production rate obtained from such processes is no longer sufficient. This has led to a growing interest in catalytic dehydrogenation, a technique that can readily accept natural gas as a feed material [2,3].

$\mathrm{CrO}_{x}$ [4-8] and Pt-based [1,3,9-13] catalysts are typical of the materials normally applied to the direct dehydrogenation (DDH) of isobutane on a commercial scale, and their favorable properties are the result of a unique combination of metals, modifiers and supports. As an example, Korhonen et al. [4] proposed that zirconia deposition on chromium/alumina could decrease the Lewis acidity of the support as well as the rate of coke formation during DDH. Tasbihi et al. [3] found that the addition of potassium and lithium to $\mathrm{Pt}-\mathrm{Sn} / \mathrm{Al}_{2} \mathrm{O}_{3}$ resulted in catalysts that exhibited higher activity and greater stability.

Other metal oxide catalysts, however, are less active. Nesterenko et al. [14] employed gallium and iron supported on MCM-41 and found that the highest conversion of isobutane over these catalysts was $45.1 \%$, with an isobutene selectivity of $52.1 \%$. Ogonowski et al. [15] prepared a series of $\mathrm{VMgO}_{x}$ catalysts with activated carbon as the support and obtained an isobutane conversion of approximately $42.0 \%$ with a selectivity for isobutene of $77.7 \%$. Metal sulfide catalysts were also studied for this reaction. Wang et al. [16] found that the performance of these catalysts was superior to that of industrial cat-

\footnotetext{
*Corresponding author. Tel/Fax: +86-10-62923564; E-mail: zpinghao@rcees.ac.cn

This work was supported by the National High Technology Research and Development Program of China (2012AA063101) and the National Natural Science Foundation of China (21337003).

DOI: 10.1016/S1872-2067(15)60914-7 | http://www.sciencedirect.com/science/journal/18722067 | Chin. J. Catal., Vol. 36, No. 8, August 2015
} 
alysts under similar operating conditions, although the potential for sulfur loss and a means of sulfur replenishment remain to be resolved.

The dehydrogenation routes applied during industrial processes use metal catalysts that often undergo rapid deactivation, and consequently there is a need for periodic regeneration of the catalyst [17]. As an example, the CATADIENE process (ABB Lummus) employs a $\mathrm{CrO}_{x} / \mathrm{Al}_{2} \mathrm{O}_{3}$ catalyst that requires regeneration after $10 \mathrm{~min}$ on stream as a result of coke buildup [18]. In addition, the use of transition metals such as $\mathrm{Cr}$ and $\mathrm{V}$ can result in severe environmental pollution, and the cost of noble metals is relatively high.

Metal-free heterogeneous catalysis using carbon is an interesting alternative to the current catalytic systems and may help to mitigate these numerous issues [19]. To date, carbon has been used primarily as a support because it offers high surface areas and tunable adsorption properties. Recent advances, however, suggest that various forms of carbon, such as activated carbon [20,21], carbon nanotubes [22-24], graphitic carbon [17,25], graphene [22,26], and nanodiamonds $[23,27,28]$, can themselves act as catalysts generating high selectivity and stability during the oxidative dehydrogenation $(\mathrm{ODH})$ reactions of alkanes. Some researchers have even suggested that, in the case of metal-based catalytic systems, the "active coke" formed during the initial stage of the reaction plays a primary role in the ODH process [29-31].

Although the ODH of isobutane typically generates a lower yield of coke and cracking products, the negative effects of having to use oxygen $\left(\mathrm{O}_{2}\right)$ in the reaction mixture limit the industrial application of this reaction. To reduce associated explosion hazards, for example, it would be preferable to perform the reaction under an inert gas, which complicates purification of the final products. In addition, $\mathrm{O}_{2}$ will react with isobutene to inevitably produce $\mathrm{CO}, \mathrm{CO}_{2}$, and other byproducts. One potential solution to this problem is to use alternative so-called soft oxidants, such as $\mathrm{N}_{2} \mathrm{O}[32,33]$ and $\mathrm{CO}_{2}$ [34,35], in place of $\mathrm{O}_{2}$, although it remains difficult to achieve satisfying yields and selectivity for the desired alkenes.

The current study first describes the use of a series of carbon materials for the DDH of isobutane without the addition of an oxidizing gas. In this work, coconut shell activated carbon (CSAC) showed encouraging catalytic activity and greater stability compared with metal catalysts. Furthermore, the effects of coke on carbon catalysts were systematically studied. In contrast to previous results $[24,36]$, we found that the active sites for the dehydrogenation of alkanes include not only surface oxygen-containing functional groups, but more importantly, the carbon itself, including the coke.

\section{Experimental}

\subsection{Reagents}

All chemicals were obtained from commercial sources and used without further purification. CSAC was purchased from the Ningxia Guanghua-Cherishmet Activated Carbon Co., Ltd., while carbon nanotubes (CNTs, 95\%) were obtained from the
Chengdu Organic Chemicals Co., Ltd. Charcoal activated carbon (CAC, A.R.), graphite (C.P.), aqueous ammonia $\left(\mathrm{NH}_{3} \cdot 4 \mathrm{H}_{2} \mathrm{O}\right.$, 25\%-28\%), resorcinol (R, A.R.), hexamethylenetetramine (HMT, A.R.), chromic nitrate $\left(\mathrm{Cr}\left(\mathrm{NO}_{3}\right)_{3} \cdot 9 \mathrm{H}_{2} \mathrm{O}\right.$, A.R.), and potassium nitrate $\left(\mathrm{KNO}_{3}\right.$, A.R.) were obtained from the Sinopharm Chemical Reagent Co., Ltd. Pluronic F127 was purchased from the Sigma Chemical Co., Ltd., aluminum sesquioxide $\left(\mathrm{Al}_{2} \mathrm{O}_{3}\right)$ was obtained from the Shandong Aluminum Co., Ltd., and the reactant gas (5\% isobutane in nitrogen) was obtained from the Beijing Hua Yuan Gas Chemical Industry Co., Ltd.

\subsection{Catalyst preparation}

The CNTs and graphite were used directly as catalysts without further treatment.

The CSAC and CAC were washed with aqueous ammonia prior to being applied to reactions. In a typical procedure, $20 \mathrm{~g}$ of activated carbon, $120 \mathrm{~mL}$ of deionized water, and $80 \mathrm{~mL}$ of aqueous ammonia were combined with vigorous stirring and heating (via a water bath) at $60^{\circ} \mathrm{C}$. After $6 \mathrm{~h}$, the treated carbon was washed with deionized water until the $\mathrm{pH}$ of the wash water had a value of 7 and then dried overnight at $100{ }^{\circ} \mathrm{C}$.

The RF-1 catalyst was synthesized using R and HMT as precursors [37]. Approximately $11.00 \mathrm{~g}$ of Pluronic F127, $3.50 \mathrm{~g}$ of HMT, $5.50 \mathrm{~g}$ of R, $260 \mathrm{~mL}$ of ultrapure water, and $11.0 \mathrm{~mL}$ of aqueous ammonia were combined with stirring at room temperature for $1 \mathrm{~h}$, and the resulting dark-green solution was further stirred with heating in a water bath at $80^{\circ} \mathrm{C}$. After continuously stirring for another $24 \mathrm{~h}$, the solid, black product was collected by sedimentation separation and washed with ultrapure water. Following overnight drying at $100{ }^{\circ} \mathrm{C}$, the sample was thermally treated at $900{ }^{\circ} \mathrm{C}$ for $2 \mathrm{~h}$, applying a heating rate of $1{ }^{\circ} \mathrm{C} / \mathrm{min}$ under a nitrogen atmosphere.

The $\mathrm{Cr}-\mathrm{K} / \mathrm{Al}_{2} \mathrm{O}_{3}$ catalyst was prepared using the impregnation method as a comparison sample for the carbon catalysts, applying $\mathrm{Cr}_{2} \mathrm{O}_{3}$ and $\mathrm{K}_{2} \mathrm{O}$ loadings of 10 and $2 \mathrm{wt} \%$, respectively. Approximately $1 \mathrm{~g}$ of the $\mathrm{Al}_{2} \mathrm{O}_{3}$ support was impregnated with an aqueous solution of $\mathrm{Cr}\left(\mathrm{NO}_{3}\right)_{3} \cdot 9 \mathrm{H}_{2} \mathrm{O}$ and $\mathrm{KNO}_{3}$ at the desired mass ratios. The resulting mixture was further stirred in a water bath until the water had completely evaporated. After additional drying at $80{ }^{\circ} \mathrm{C}$ for $5 \mathrm{~h}$, the sample was treated at $600{ }^{\circ} \mathrm{C}$ for $2 \mathrm{~h}$ at a heating rate of $3{ }^{\circ} \mathrm{C} / \mathrm{min}$ under an air atmosphere.

\subsection{Catalytic activity measurements during DDH of isobutane}

Catalytic tests were performed using a fixed glass tube reactor ( $6 \mathrm{~mm}$ in diameter). The reaction feed consisted of $5 \%$ isobutane in $\mathrm{N}_{2}$, and the combined gas flow rate was maintained at $20 \mathrm{~mL} / \mathrm{min}$ (weight hourly space velocity (WHSV) of $6000 \mathrm{~mL} \mathrm{~g}^{-1} \mathrm{~h}^{-1}$ ). The reactants and products were analyzed using an Agilent 7890A gas chromatograph equipped with a Poropak N column (Agilent, HP-PLOT $\mathrm{Al}_{2} \mathrm{O}_{3} \mathrm{~S}$ ) and a flame ionization detector, using $\mathrm{N}_{2}$ (99.99\%) as the carrier gas.

The catalyst behavior was evaluated in terms of the following parameters, where $F$ is the molar flow rate and subscripts $\mathrm{i}$ and o indicate values measured at the inlet and outlet, respectively [20]: 
Conversion of isobutane $=\left[F_{\mathrm{i}}(\right.$ isobutane $)-F_{\mathrm{o}}($ isobutane $\left.)\right] /$ $F_{\mathrm{i}}$ (isobutane) $\times 100 \%$

Yield of isobutene $=F_{\mathrm{o}}($ isobutene $) / F_{\mathrm{i}}($ isobutane $) \times 100 \%$ Selectivity for isobutene $=F_{\mathrm{o}}($ isobutene $) /\left[F_{\mathrm{i}}\right.$ (isobutane $)-$ $F_{\mathrm{o}}$ (isobutane) $] \times 100 \%$

\subsection{Material characterization}

$\mathrm{N}_{2}$ adsorption-desorption isotherms were acquired at the temperature of liquid nitrogen using a gas adsorption analyzer (ASAP 2020H). The specific surface areas were calculated using the BET method, and the pore volumes and pore size distributions were derived by employing the BJH model. All samples were degassed at $200{ }^{\circ} \mathrm{C}$ for $3 \mathrm{~h}$ prior to measurements.

Isobutane adsorption-desorption isotherms were obtained at $25{ }^{\circ} \mathrm{C}$ using an intelligent gravimetric analyzer (IGA, Hiden Isochema Ltd., Warrington, UK). The specific surface areas were also calculated using the BET method, which was valid over the range of $p / p_{0}$ from approximately 0.05 to 0.25 . All samples were degassed at $200^{\circ} \mathrm{C}$ for $3 \mathrm{~h}$ before measurements.

X-ray photoelectron spectra (XPS) were recorded with a Thermo ESCALAB 250 instrument using $\mathrm{Al} K_{\alpha}$ radiation at a base pressure of $50 \mathrm{nPa}$. Binding energies (BE) were calibrated using the $\mathrm{C} 1 \mathrm{~s}$ peak of contaminant carbon $(\mathrm{BE}=285 \mathrm{eV})$ as the standard and had a precision of $\pm 0.2 \mathrm{eV}$.

Thermogravimetry (TG) and differential scanning calorimetry (DSC) data were obtained using a Mettler Toledo TGA/DSC-1 instrument and employing a sample size of approximately $8 \mathrm{mg}$, under a dynamic air atmosphere (100 $\mathrm{ml} / \mathrm{min}$ ) at a heating rate of $5^{\circ} \mathrm{C} / \mathrm{min}$ and over the temperature range from 25 to $700^{\circ} \mathrm{C}$.

Fourier transform infrared (FTIR) spectra were recorded on a Nicolet 8700 FTIR spectrometer over the range of 500 to $4500 \mathrm{~cm}^{-1}$ with a scanning step size of $2.14 \mathrm{~cm}^{-1}$. All samples were analyzed in the form of $\mathrm{KBr}$ pellets.

Field-emission scanning electron microscopy (FE-SEM) images were obtained on a Hitachi SU 8020 using a tungsten electron source and an accelerating voltage of $10 \mathrm{kV}$.

\section{Results and discussion}

\subsection{Catalytic activity of carbon catalysts}

Various carbon materials were applied to the isobutane $\mathrm{DDH}$ reaction at $625^{\circ} \mathrm{C}$, and the resulting isobutane conversion and isobutene selectivity data are summarized in Fig. 1. Here the conversions are shown as functions of time-on-stream for the selection of catalysts. The main reaction byproducts were found to be methane and propene, which together accounted for $84 \%$ to $98 \%$ of all byproducts, depending on the carbon catalyst. Small amounts of ethane, ethane, and propane were also detected. A blank reaction trial over glass wool showed that the conversion of isobutane in the absence of the catalyst (about 4\%) was negligible.

The CSAC catalyst exhibited good catalytic performance, with a $70 \%$ conversion and a selectivity for isobutene of approximately $78 \%$. The other carbon materials were also effi-

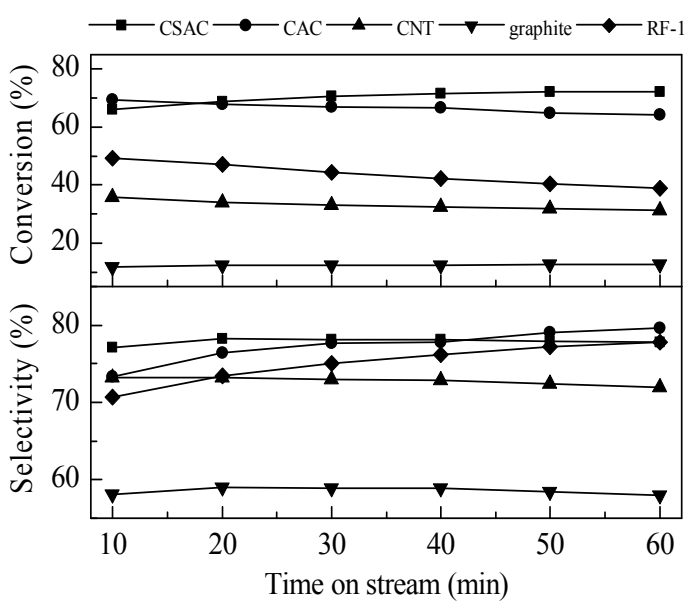

Fig. 1. Catalytic activity of various carbon catalysts at $625^{\circ} \mathrm{C}$ and $0.4 \mathrm{~g}$ catalyst.

cient catalysts for this reaction. The conversions of isobutane over CAC, CNT, and RF-1 were $67 \%, 33 \%$, and $45 \%$, respectively, with the selectivities for isobutene ranging from $72 \%$ to $77 \%$. Graphite had the lowest catalytic activity with a conversion of $12 \%$ and selectivity of only $58 \%$.

The effects of the reaction temperature and the amount of catalyst were evaluated, and the results are shown in Figs. 2 and 3 , respectively. The isobutane conversions over the CSAC were about $22 \%$ and $97 \%$ at 550 and $700{ }^{\circ} \mathrm{C}$, respectively, and thus increased with the reaction temperature. In contrast, the selectivity for isobutene showed an obvious decreasing tendency such that, at $700{ }^{\circ} \mathrm{C}$, the selectivity was $30 \%$ with a yield of only $28 \%$. The optimal reaction temperature was $625{ }^{\circ} \mathrm{C}$, at which the yield and selectivity were $55 \%$ and $79 \%$, respectively.

The conversion of isobutane over $0.2 \mathrm{~g}$ of the CSAC was only $52 \%$ with a yield of $43 \%$, while the use of $0.4 \mathrm{~g}$ of the catalyst increased the conversion significantly, to $70 \%$. Further increases in the amount of the catalyst did not generate any additional yield because of the decreased selectivity.

The stabilities of the catalysts are summarized in Fig. 4. For comparison, the typical catalyst $\mathrm{Cr}-\mathrm{K} / \mathrm{Al}_{2} \mathrm{O}_{3}$ was also assessed

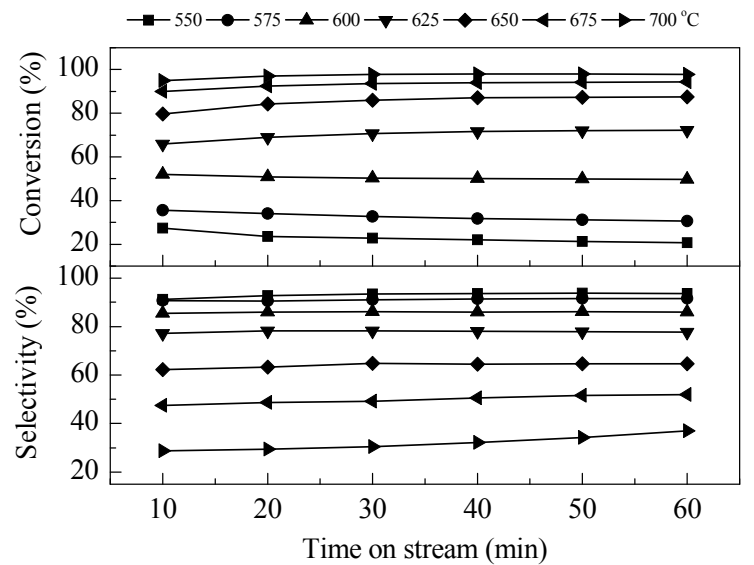

Fig. 2. Effect of reaction temperature when using $0.4 \mathrm{~g}$ CSAC catalyst. 


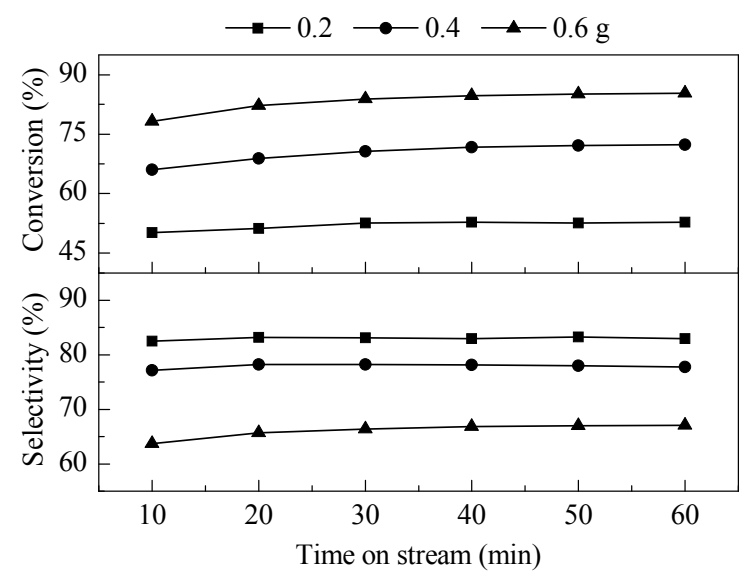

Fig. 3. Effect of the amount of the CSAC catalyst at $625^{\circ} \mathrm{C}$.

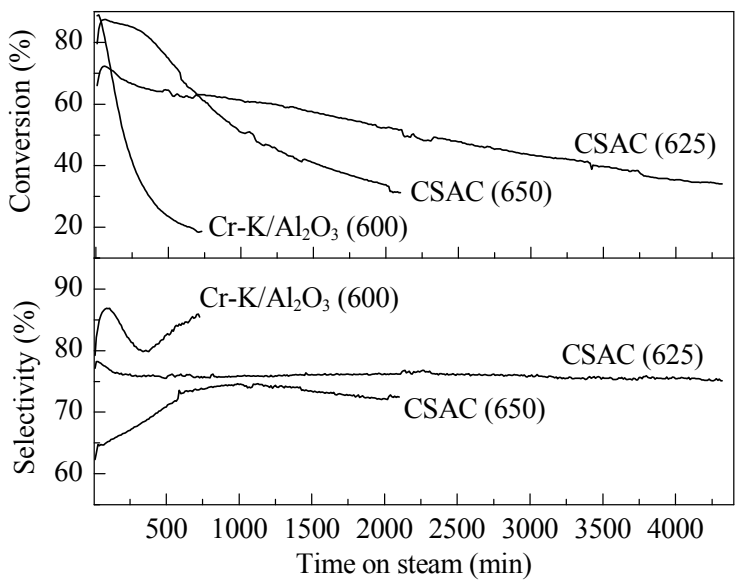

Fig. 4. Catalyst stability over time using $0.4 \mathrm{~g}$ catalyst. Reaction temperatures $\left({ }^{\circ} \mathrm{C}\right)$ are shown in parentheses.

at $600{ }^{\circ} \mathrm{C}$. Initially, the conversion of isobutane over this material was as high as $89 \%$ with a selectivity of $82 \%$; however, a rapid deactivation occurred over time. The conversion of isobutane decreased to $19 \%$ in just $12 \mathrm{~h}$, caused by rapid and heavy coke deposition during the reaction.

The CSAC showed significantly better stability at $625{ }^{\circ} \mathrm{C}$.

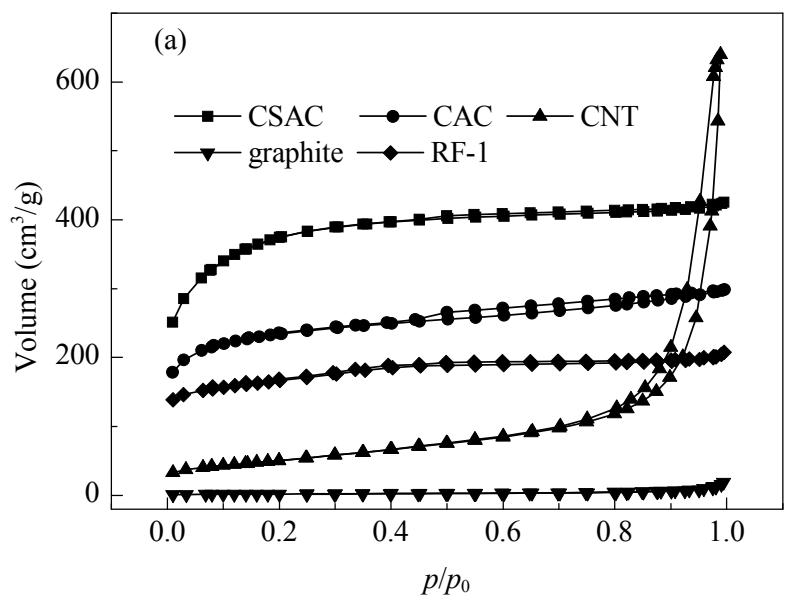

Table 1

Surface properties and porosities of various carbon catalysts.

\begin{tabular}{lrrrrc}
\hline \multirow{2}{*}{ Sample } & \multicolumn{3}{c}{$\mathrm{N}_{2}$ adsorbate } & & Isobutene adsorbate \\
\cline { 2 - 3 } \cline { 5 - 5 } & $S_{\text {BET }}\left(\mathrm{m}^{2} / \mathrm{g}\right)$ & $V_{\mathrm{P}}\left(\mathrm{cm}^{3} / \mathrm{g}\right)$ & $D_{\mathrm{P}}(\mathrm{nm})$ & & $S_{\text {BET }}\left(\mathrm{m}^{2} / \mathrm{g}\right)$ \\
CSAC & 1190.2 & 0.66 & 2.3 & & 754.6 \\
CAC & 733.3 & 0.46 & 3.1 & & 436.7 \\
CNT & 180.2 & 0.99 & 19.3 & & 127.4 \\
Graphite & 7.6 & 0.03 & 14.6 & & 4.7 \\
RF-1 & 528.9 & 0.32 & 2.9 & & 151.9 \\
\hline
\end{tabular}

\section{Table 2}

Surface properties and physical properties of fresh and used CSAC catalysts.

\begin{tabular}{|c|c|c|c|c|}
\hline \multirow{2}{*}{ CSAC } & \multicolumn{3}{|c|}{$\mathrm{N}_{2}$ adsorbate } & \multirow{2}{*}{$\begin{array}{c}\text { Isobutane adsorbate } \\
S_{\mathrm{BET}}\left(\mathrm{m}^{2} / \mathrm{g}\right) \\
\end{array}$} \\
\hline & $S_{\mathrm{BET}}\left(\mathrm{m}^{2} / \mathrm{g}\right)$ & $V_{\mathrm{P}}\left(\mathrm{cm}^{3} / \mathrm{g}\right)$ & $D_{\mathrm{P}}(\mathrm{nm})$ & \\
\hline Fresh & 1190.2 & 0.66 & 2.3 & 754.6 \\
\hline Used-1 $\mathrm{d}^{\mathrm{a}}$ & 780.2 & 0.44 & 2.3 & 487.0 \\
\hline Used-2d a & 392.4 & 0.23 & 2.4 & 235.5 \\
\hline Used-3d a & 343.3 & 0.20 & 2.4 & 205.3 \\
\hline
\end{tabular}

${ }^{a}$ The numeral in the sample name refers to the number of days for which the reaction proceeded.

Over the course of $3 \mathrm{~d}$, the conversion of isobutane slowly decreased from $71 \%$ to $34 \%$ while the selectivity remained at approximately $76 \%$. It was also evident from these data that a higher reaction temperature improves the catalytic activity.

\subsection{Surface properties and porosities of carbon catalysts}

As presented in Table 1 and Fig. 5, the surface properties and porosities of various carbon catalysts were studied using $\mathrm{N}_{2}$ adsorption-desorption. Static adsorption studies using isobutane as the adsorbate were also performed to obtain another series of BET-specific surface areas for comparison, as also shown in Fig. 5.

The $\mathrm{N}_{2}$ and isobutane BET-specific surface areas of CSAC were 1190.2 and $754.6 \mathrm{~m}^{2} / \mathrm{g}$, respectively, both of which are considerably larger than the values obtained for the other carbon materials. This may be associated with the higher catalytic activity of the CSAC.

As shown in Table 2 and Fig. 6, a CSAC sample showed similar type I adsorption isotherms in both fresh and used states, according to the IUPAC classification system [38]. Following its

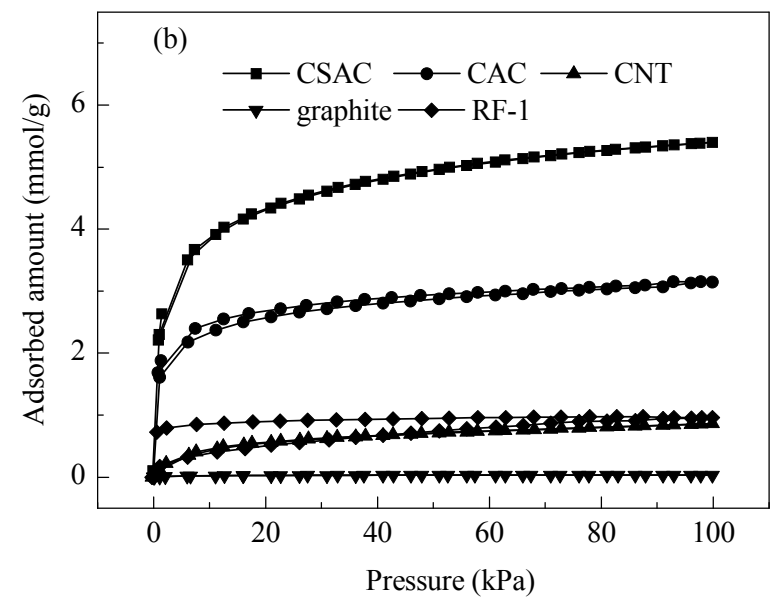

Fig. 5. Adsorption-desorption isotherms of various carbon catalysts when adsorbing $\mathrm{N}_{2}$ (a) and isobutane (b). 

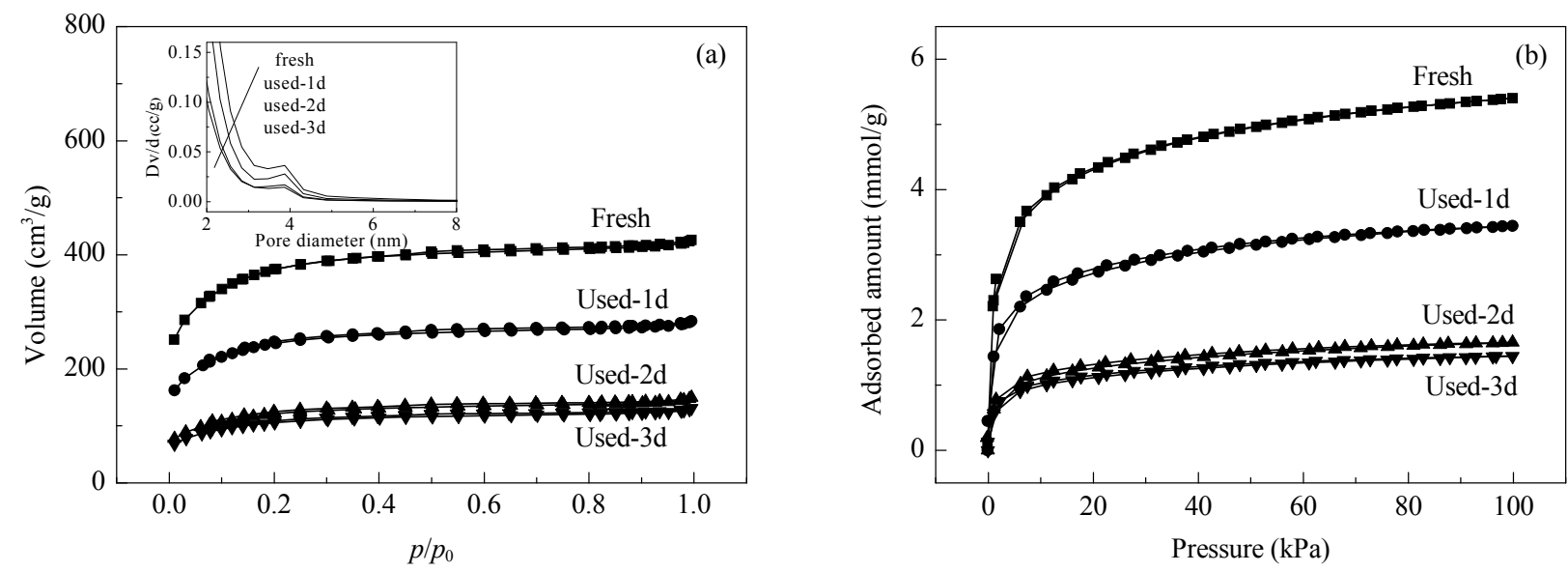

Fig. 6. Adsorption-desorption isotherms and BJH pore size distributions of the CSAC catalysts, both fresh and after reuse. (a) $\mathrm{N}_{2}$ adsorbate; (b) Isobutane adsorbate.

use in the isobutane reaction, the adsorption capacity of the material decreased significantly after running for $3 \mathrm{~d}$. The BET-specific surface area, average pore volume, and pore radius of the sample all decreased following its application to the reaction. This was attributed to the hard, dense coke covering the surfaces of the CSAC, and blocking its micropores $[39,40]$. Based on the $\mathrm{N}_{2}$ adsorption-desorption results, the $S_{\mathrm{BET}}$ and $V_{\mathrm{P}}$ decreased to $343.3 \mathrm{~m}^{2} / \mathrm{g}$ and $0.20 \mathrm{~cm}^{3} / \mathrm{g}$, respectively. This explains why the conversion of isobutane over the CSAC decreased with reaction time.

We subsequently investigated the correlation between the $\mathrm{N}_{2}$ surface areas of CSAC catalysts (calculated by multiplying the specific surface area by the amount of catalyst) and the isobutane conversion, with the results shown in Fig. 7. It is notable that the data from both fresh and used catalysts fall on the same plot, implying that the deposited coke might be catalytically active. A similar isobutane adsorption-desorption study provided similar results.

\subsection{Surface analysis of CSAC catalysts}

The XPS spectra and elemental compositions of a fresh and used CSAC catalyst are provided in Fig. 8 and Table 3. The samples exhibit a strong $\mathrm{C} 1 \mathrm{~s}$ peak at a binding energy of approxi-

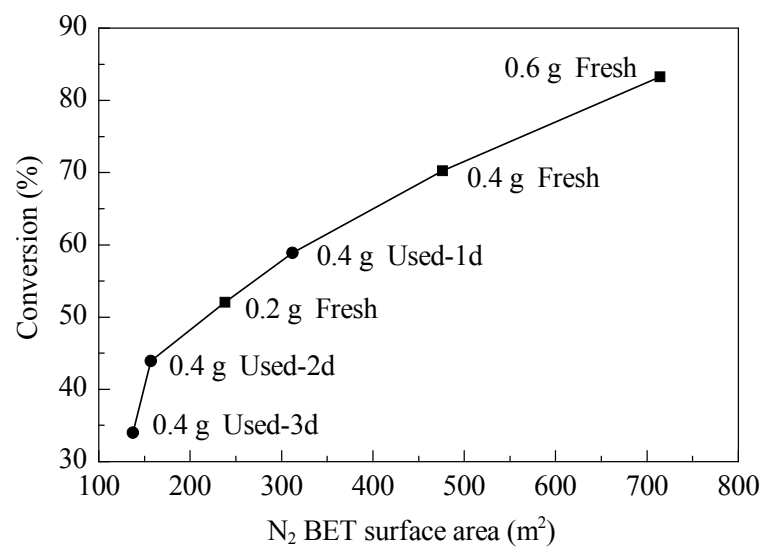

Fig. 7. Correlation between $\mathrm{N}_{2}$ BET surface area and conversion of isobutane. mately $284.6 \mathrm{eV}$ and a weak peak at approximately $533.1 \mathrm{eV}$, assigned to $01 s$. It was determined that the oxygen concentrations on the fresh and used CSAC were approximately $4.43 \%$ and $3.78 \%$, respectively. This oxygen may have been due to the adsorption of water from the surrounding air. Traces of silicon and chlorine were also detected.

Fig. 9 provides more detailed plots of the XPS C $1 s$ and $01 s$ peaks of the fresh and used CSAC catalyst. Deconvolution of the $\mathrm{C} 1 \mathrm{~s}$ peak in Fig. 9(a) indicates that both specimens have similar spectra, in agreement with recent photoemission studies [41-43]. The main peak at $284.6 \mathrm{eV}$ is attributed to a graphitic structure, while the peak at $286.1 \mathrm{eV}$ results from defects in the surface structure and those at approximately 287.1 and 290.0 $\mathrm{eV}$ correspond to carbon atoms attached to different oxygen-containing groups. Following the reaction, the $\mathrm{C} 1 \mathrm{~s}$ peak at $289.9 \mathrm{eV}$, attributed to carbonates, is seen to increase. Deconvolution of the XPS $01 s$ peak (Fig. 9(b)) confirms the presence of some carboxylic and hydroxyl functions on the CSAC surface

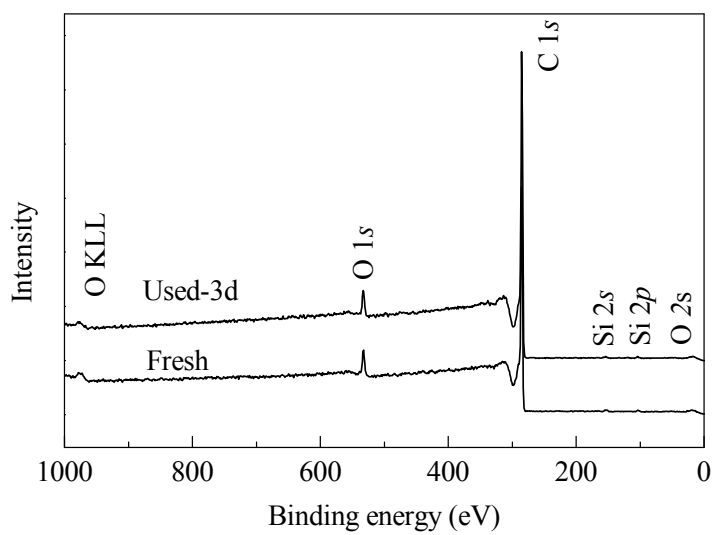

Fig. 8. XPS spectra of a CSAC specimen in both fresh and used states.

Table 3

Elemental analysis of a fresh and used CSAC catalyst.

\begin{tabular}{lcccc}
\hline \multirow{2}{*}{ CSAC } & \multicolumn{5}{c}{ Concentration (\%) } \\
\cline { 2 - 5 } & $\mathrm{C} 1 s$ & $01 s$ & Si $2 p$ & $\mathrm{Cl} 2 p$ \\
\hline Fresh & 94.83 & 4.43 & 0.73 & 0.02 \\
Used-3d & 95.75 & 3.78 & 0.47 & - \\
\hline
\end{tabular}



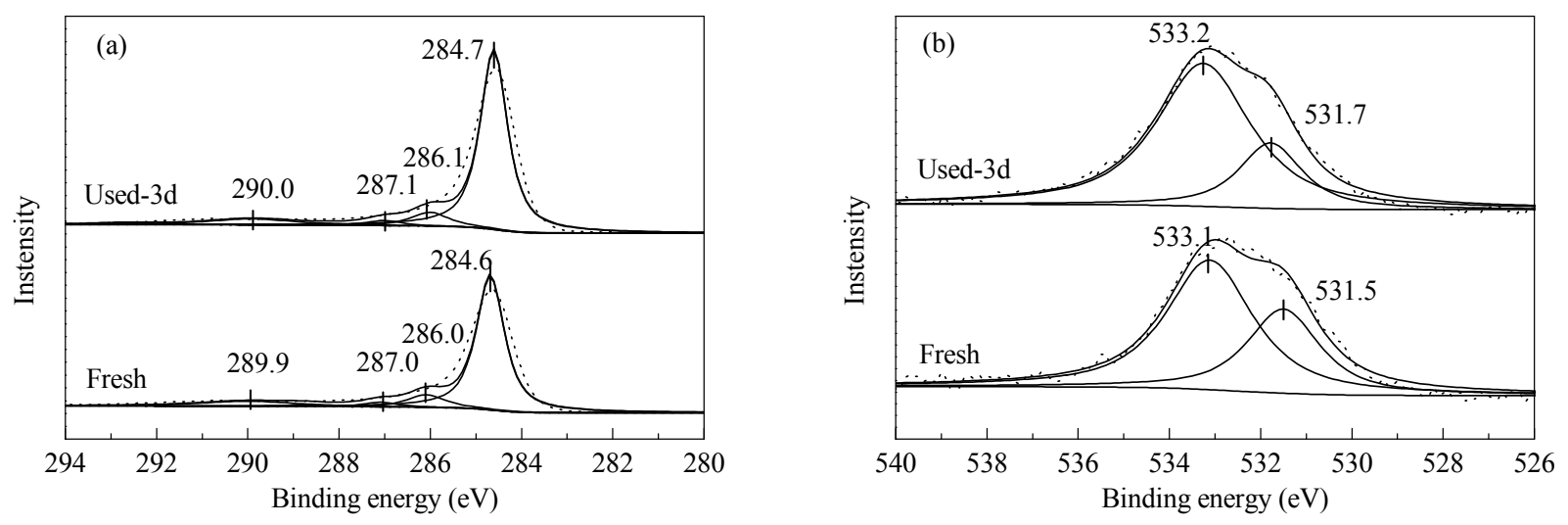

Fig. 9. Deconvolution of the XPS C $1 s(\mathrm{a})$ and $01 s(\mathrm{~b})$ peaks of a fresh and used CSAC catalyst.

based on the peaks at approximately 533.2 and $531.7 \mathrm{eV}$, respectively $[41,43]$. Similarly, the peak at $533.1 \mathrm{eV}$ resulting from carbonate functionalities is also more intense. These results indicate the deposition of coke during the reaction.

\subsection{Thermal analysis of CSAC catalysts}

As shown in Fig. 10, both the fresh and used CSAC catalyst generated similar TG curves, suggesting that the samples were completely degraded prior to reaching $635^{\circ} \mathrm{C}$. The DSC curves indicate the occurrence of an exothermic event in the range of 465 to $635^{\circ} \mathrm{C}$, which may be attributed to decomposition of the catalyst. The fresh CSAC showed an exotherm at $617^{\circ} \mathrm{C}$ but this was shifted to $609{ }^{\circ} \mathrm{C}$ after the reaction and the peak area was also observed to increase. These changes are attributed to the formation of coke during the reaction, representing a structurally less ordered form of carbon that is less resistant to oxidation than the CSAC [44].

\subsection{Functional group analysis of the CSAC catalyst}

The FTIR spectra of the CSAC catalyst in the fresh state and after being applied to the reaction are shown in Fig. 11. The fresh catalyst generated peaks at 3417, 2961, 2921, 2868, $1700,1609,1453,1382,1046$, and $882 \mathrm{~cm}^{-1}$, most of which have been previously attributed to active carbon [45-48]. The

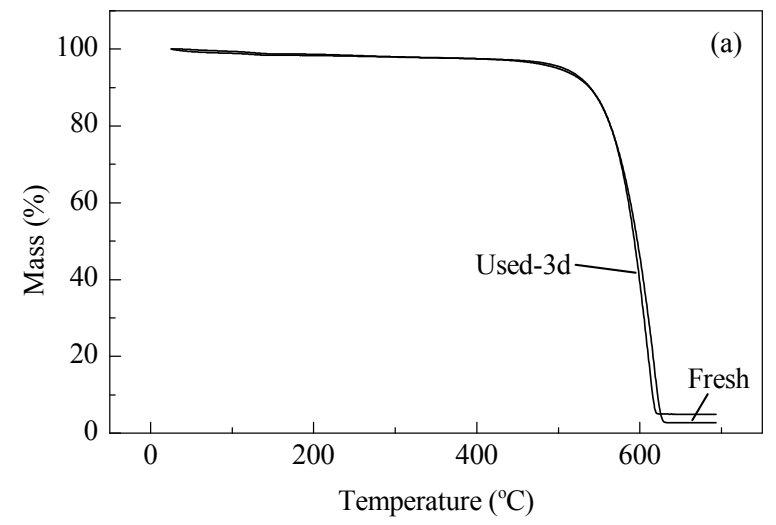

band at $3417 \mathrm{~cm}^{-1}$ can be assigned to the $-\mathrm{OH}$ stretching vibration mode of hydroxyl functional groups, while the bands around $2900 \mathrm{~cm}^{-1}$ originate from the $\mathrm{CH}$ stretching vibration and those at 1700 and $1609 \mathrm{~cm}^{-1}$ are due to the stretching vibration of carboxyl groups. The peaks at 1453 and $1382 \mathrm{~cm}^{-1}$ are ascribed to $\mathrm{C}-0$ stretching and the band around $800 \mathrm{~cm}^{-1}$ may be attributed to out-of-plane bending in benzene derivatives.

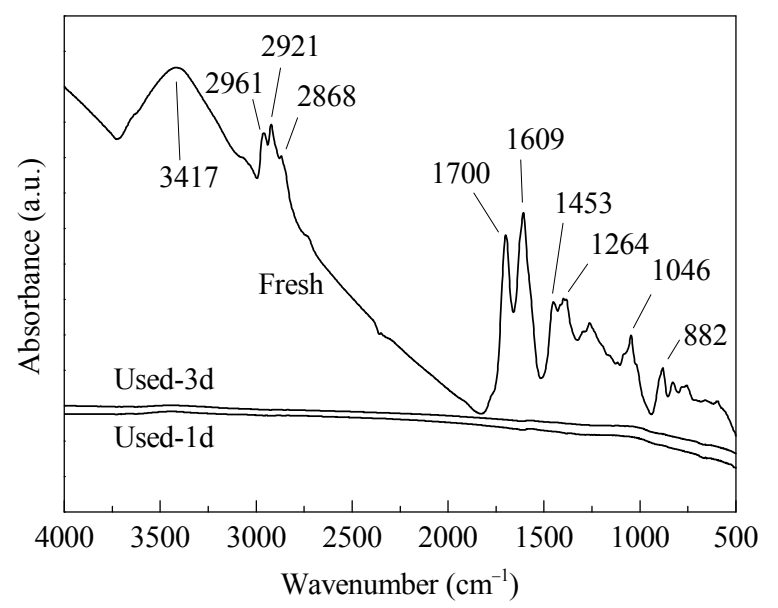

Fig. 11. FTIR spectra of a CSAC catalyst both fresh and after repeated uses.

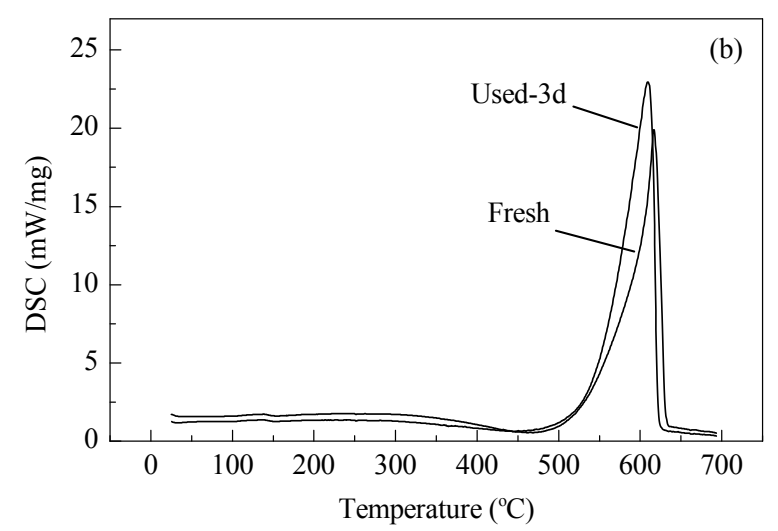

Fig. 10. TG (a) and DSC (b) curves of a fresh and used CSAC catalyst. 
Significant changes are observed in the spectra of the used catalysts such that nearly all of the absorbance bands disappear, indicating that the high reaction temperature resulted in a rapid disappearance of the functional groups on the CSAC surface. These data are in good agreement with the XPS results. While CSAC retained its catalytic activity after use, we conclude that the presence of various surface functional groups is not necessary for catalysis of the DDH reaction, in contrast to the conclusions of previous reports [24,36].

\subsection{Morphological properties of CSAC catalysts}

FE-SEM micrographs of the CSAC catalyst both fresh and after use are presented in Fig. 12 and show the effect of coke deposition on the surface of the catalyst during the reaction. In Fig. 12(a), the fresh CSAC catalyst has flat surfaces and sharp edge angles. In Fig. 12(b) and (c), after performing the reaction at $625{ }^{\circ} \mathrm{C}$, the surfaces are rough and coke has accumulated on some parts to produce rounded structures, such that the surface is markedly different from that of the fresh CSAC. After reacting for $3 \mathrm{~d}$, the round structures cover substantial portions of the catalyst surface, and flocculent coke is also observed, as shown in Fig. 12(d). These results suggest that, similar to metal catalysts, coke is deposited on carbon catalysts. This explains why the specific surface areas of CSAC catalysts slowly decrease with use.

\subsection{Factors affecting the catalytic activity of carbon catalysts}

The FTIR and XPS results suggest the rapid disappearance of the functional groups on the surface of CSAC, even though the CSAC continues to exhibit catalytic activity, indicating that the functional groups are not necessary for catalysis of the DDH reaction. More importantly, these results imply that carbon itself may be active for the DDH reaction and that the coke may be as active as the CSAC, CNT, and RF-1 used in this work.

Although coke deposition decreased the specific surface area of the CSAC, both fresh and used catalysts showed the same correlation between the surface area of catalysts and the con-

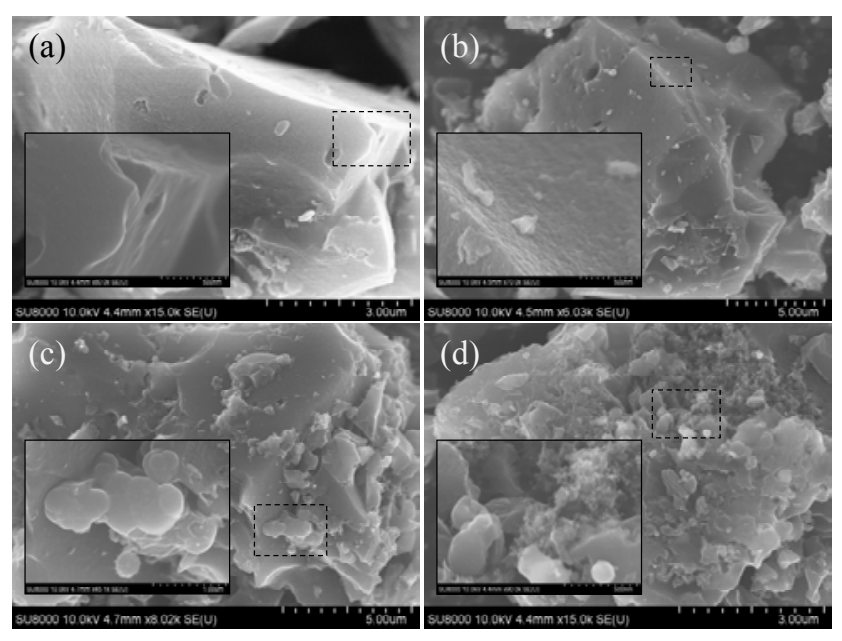

Fig. 12. FE-SEM micrographs of a CSAC catalyst. (a) Fresh; (b) Used-1d; (c) Used-2d; (d) Used-3d. version of isobutane, so it is not possible to say that the coke covered the original active sites. As such, the coke generated during the reaction must also be catalytically active. This finding is consistent with past studies that have shown that so-called "active coke" may play a primary role in the dehydrogenation reaction [29-31]. The specific surface area is therefore the main factor affecting the catalytic activity.

\section{Conclusions}

An efficient and practical means of promoting the DDH of isobutane to isobutene was realized based on the use of carbon materials, with an isobutane conversion of $70 \%$ over CSAC at $625^{\circ} \mathrm{C}$. This system showed encouraging catalytic performance without the use of additional oxidizing gases or the deposition of metal particles. In addition, the CSAC exhibited catalytic stability superior to that of conventional catalysts and was able to maintain a selectivity of approximately $76 \%$. The most fundamental determinant of the catalytic activity of both fresh and used carbon catalysts was found to be the specific surface area. Deposited coke decreased the catalytic activity by reducing the specific surface area of the material, although carbon materials (including the deposited coke) without functional groups were shown to function as effective catalysts. The regeneration of carbon catalysts such as those included in this work should be explored in future studies.

\section{References}

[1] Casella M L, Siri G J, Santori G F, Ferretti O A, Ramírez-Corredores M M. Langmuir, 2000, 16: 5639

[2] Cortright R D, Hill J M, Dumesic J A. Catal Today, 2000, 55: 213

[3] Tasbihi M, Feyzi F, Amlashi M A, Abdullah A Z, Mohamed A R. Fuel Process Technol, 2007, 88: 883

[4] Korhonen S T, Airaksinen S M K, Bańares M A, Krause A O I. Appl Catal A, 2007, 333: 30

[5] Neri G, Pistone A, De Rossi S, Rombi E, Milone C, Galvagno S. Appl Catal A, 2004, 260: 75

[6] Airaksinen S M K, Harlin M E, Krause A O I. Ind Eng Chem Res, 2002, 41: 5619

[7] Zimmermann H, Versluis F. US Patent 5378350.1995

[8] Buonomo F, Jezzi R, Notari B, Kotelnikov G R, Mikhailov K R, Patanov V A. US Patent 4746 643. 1988

[9] Bentahar F Z, Candy J P, Basset J M, Le Peltier F, Didillon B. Catal Today, 2001, 66: 303

[10] Siri G J, Ramallo-López J M, Casella M L, Fierro J L G, Requejo F G, Ferretti O A. Appl Catal A, 2005, 278: 239

[11] Delsarte S, Maugé F, Grange P.J Catal, 2001, 202: 1

[12] Iezzi R, Buonomo F, Sanfilippo D. US Patent 5143886.1992

[13] Herber R R, Thompson G J. US Patent 4806624.1989

[14] Nesterenko N S, Ponomoreva O A, Yuschenko V V, Ivanova I I, Testa F, Di Renzo F, Fajula F. Appl Catal A, 2003, 254: 261

[15] Ogonowski J, Skrzyńska E. Catal Lett, 2006, 111: 79

[16] Wang G W, Li C Y, Shan H H. ACS Catal, 2014, 4: 1139

[17] Xie H, Wu Z L, Overbury S H, Liang C D, Schwartz V. J Catal, 2009, 267: 158

[18] McGregor J, Huang Z Y, Parrott E P J, Zeitler J A, Nguyen K L, Rawson J M, Carley A, Hansen T W, Tessonnier J P, Su D S, Teschner D, Vass E M, Knop-Gericke A, Schlögl R, Gladden L F. J Catal, 2010, 


\title{
Graphical Abstract
}

Chin. J. Catal., 2015, 36: 1214-1222 doi: 10.1016/S1872-2067(15)60914-7

\section{Direct dehydrogenation of isobutane to isobutene over carbon catalysts}

Yang Li, Zhongshen Zhang, Junhui Wang, Chunyan Ma, Hongling Yang, Zhengping Hao* Research Center for Eco-Environmental Sciences, Chinese Academy of Sciences

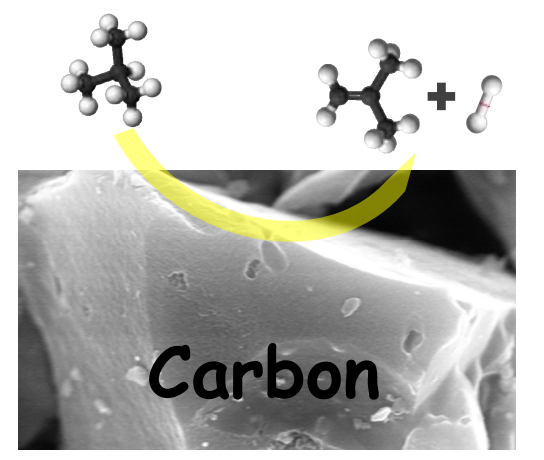

Various carbon materials were applied as catalysts for the direct dehydrogenation of isobutane. Coconut shell activated carbon exhibited a high conversion value of $70 \%$ and superior catalytic stability compared with conventional catalysts. Carbon materials (including coke) lacking functional groups were found to function as effective catalysts.

\section{9: 329}

[19] Schwartz V, Xie H, Meyer H M III, Overbury S H, Liang C D. Carbon, 2011, 49: 659

[20] de Jesús Díaz Velásquez J, Suárez L M C, Figueiredo J L. Appl Catal A, 2006, 311: 51

[21] Zhang J, Jin Y, Li C Y, Shen Y N, Han L, Hu Z X, Di X W, Liu Z L. Appl Catal B, 2009, 91: 11

[22] Jang D Y, Jang H G, Kim G R, Kim G J. Res Chem Intermed, 2011, 37: 1145

[23] Liu X, Frank B, Zhang W, Cotter T P, Schlögl R, Su D S. Angew Chem Int Ed, 2011, 50: 3318

[24] Zhang J, Liu X, Blume R, Zhang A H, Schlögl R, Su D S. Science, 2008, 322: 73

[25] Liang C D, Xie H, Schwartz V, Howe J, Dai S, Overbury S H. J Am Chem Soc, 2009, 131: 7735

[26] Dathar G K P, Tsai Y T, Gierszal K, Xu Y, Liang C D, Rondinone A J, Overbury S H, Schwartz V. ChemSusChem, 2014, 7: 483

[27] Zhang J, Su D S, Zhang A H, Wang D, Schlögl R, Hébert C. Angew Chem Int Ed, 2007, 46: 7319

[28] Su D S, Maksimova N I, Mestl G, Kuznetsov V L, Keller V, Schlögl R, Keller N. Carbon, 2007, 45: 2145

[29] Zarubina V, Nederlof C, van der Linden B, Kapteijn F, Heeres H J, Makkee M, Melián-Cabrera I. J Mol Catal A, 2014, 381: 179

[30] Abello M C, Gomez M F, Cadús L E. Ind Eng Chem Res, 1996, 35: 2137

[31] Su D S, Delgado J J, Liu X, Wang D, Schlögl R, Wang L F, Zhang Z,
Shan Z C, Xiao F S. Chem Asian J, 2009, 4: 1108

[32] Kondratenko E V, Baerns M. Appl Catal A, 2001, 222: 133

[33] Bulánek R, Wichterlová B, Novoveská K, Kreibich V. Appl Catal A, 2004, 264: 13

[34] Ansari M B, Park S E. Energy Environ Sci, 2012, 5: 9419

[35] Michorczyk P, Pietrzyk P, Ogonowski J. Microporous Mesoporous Mater, 2012, 161: 56

[36] Liu X, Su D S, Schlögl R. Carbon, 2008, 46: 547

[37] Liu D, Lei J H, Guo L P, Qu D Y, Li Y, Su B L. Carbon, 2012, 50: 476

[38] Shim J W, Park S J, Ryu S K. Carbon, 2001, 39: 1635

[39] Xu G W, Ikegami M, Honma S, Ikeda K, Mao X X, Nagaishi H. Energy Fuels, 2003, 17: 779

[40] Das S, Sharma S, Choudhury R. Energy, 2002, 27: 405

[41] Datsyuk V, Kalyva M, Papagelis K, Parthenios J, Tasis D, Siokou A, Kallitsis I, Galiotis C. Carbon, 2008, 46: 833

[42] Boehm H P. Carbon, 2002, 40: 145

[43] Goh H W, Goh S H, Xu G Q, Pramoda K P, Zhang W D. Chem Phys Lett, 2003, 379: 236

[44] Rodriguez N M, Chambers A, Baker R T K. Langmuir, 1995, 11: 3862

[45] Deng H, Yang L, Tao G H, Dai J L. J Hazard Mater, 2009, 166: 1514

[46] Deng H, Zhang G L, Xu X L, Tao G H, Dai J L. J Hazard Mater, 2010, 182: 217

[47] Zhong M, Wang Y, Yu J, Tian Y J, Xu G W. Particuology, 2012, 10: 35

[48] Xu C W, Cheng L Q, Shen P K, Liu Y L. Electrochem Commun, 2007, 9: 997

\section{碳催化剂用于异丁烷直接脱氢制异丁烯}

\author{
李 杨, 张中申, 王俊慧, 麻春艳, 杨洪玲, 郝郑平 ${ }^{*}$ \\ 中国科学院生态环境研究中心, 北京 100085
}

摘要: 异丁烯用途广泛, 被认为是除乙烯和丙烯外最重要的基础化工原料. 异丁烯的来源主要是石油裂化过程中产生的碳四馏 分, 但随着对其需求量的逐年增加, 分离法已逐渐无法满足, 因此异丁烷直接脱氢工艺逐渐受到工业界和学术界的重视. 铬系和 铂系催化剂是两类传统工业催化体系, 但铭对环境污染严重, 铂作为贵金属成本较高, 而且现有工艺大多存在催化剂稳定性较差 需要反复再生的问题. 近年来碳材料用于烷烃氧化脱氢反应的研究较多, 并表现出较高的活性和稳定性, 甚至有研究组提出金属 催化剂在反应中快速生成的活性积碳(active coke)可能是真正的催化活性中心. 但氧化脱氢反应不同于直接脱氢, 需在反应中加 入氧气, 这在实际生产中会带来一系列问题: 考虑到烷烃的爆炸极限, 实际应用时反应气必须稀释, 这不利于产物的收集; 而且氧 气会导致反应物过度氧化产生 $\mathrm{CO}$ 和 $\mathrm{CO}_{2}$ 等副产物, 也限制了氧化脱氢工艺在工业上的应用和发展.

我们研究组将椰壳碳、煤质碳和碳纳米管等碳材料作为催化剂用于催化异丁烷直接脱氢反应, 发现碳催化剂表现出较高的催 
化活性: 在 $625^{\circ} \mathrm{C}$, 楖壳碳上异丁烷转化率和异丁烯选择性分别为 $70 \%$ 和 $78 \%$, 连续反应 $3 \mathrm{~d}$ 后仍能维持 $34 \%$ 的转化率, 且选择性基 本不变. 与铬基催化剂相比, 碳催化剂在稳定性方面表现出更大优势. 我们进一步采用 $\mathrm{N}_{2}$ 吸脱附、X射线光电子能谱(XPS)、傅里 叶变换红外光谱(FTIR)和场发射扫描电子显微镜(FE-SEM)等手段对反应前后的碳催化剂进行了详细表征. $\mathrm{N}_{2}$ 吸脱附结果表明, 楖壳碳比表面积高达 $1190.2 \mathrm{~m}^{2} / \mathrm{g}$, 这可能是其具有较高催化活性的原因; 而结合催化剂活性数据, 对比反应前后椰壳碳催化剂比 表面积和异丁烷转化率可知, 两者呈现近乎线性的相关性, 进一步证实比表面积大小对碳催化剂催化活性有重要影响. XPS谱图 证明楖壳碳在反应前表面除了有少量硅 $(0.73 \%)$ 外, 不存在金属氧化物等杂质, 证实碳材料无需负载氧化物等即可表现出较高的 催化活性; 反应后沉积的积碳附着在催化剂表面, 使硅含量降低至 $0.47 \%$; 催化剂中氧含量也由 $4.43 \%$ 降低至 $3.78 \%$, 同时有碳酸 盐生成. FTIR谱图进一步证实反应前的楖壳碳表面有丰富的有机官能团, 但反应开始后有机官能团很快消失, 而催化剂仍保持较 高的催化活性, 因此有机官能团并非碳催化剂催化活性高的必要因素, 这与文献中已报道的结果不同. FE-SEM照片中观察到反 应后楖壳碳催化剂表面形成积碳, 随着反应时间延长积碳明显增多,这与XPS结果一致.

碳材料具有来源广泛、绿色环保等显著优势, 可作为一种新的催化体系应用于异丁烷直接脱氢反应,无需负载其他物质或添 加氧化性气体即可表现出良好的催化活性和稳定性, 其比表面积对催化活性有重要影响, 反应中产生的积碳导致催化剂比表面积 下降进而降低其催化活性, 而有机官能团的存在对催化活性影响不大.

关键词: 碳; 直接脱氢; 异丁烷; 异丁烯; 多相催化

收稿日期: 2015-02-28. 接受日期: 2015-05-18. 出版日期: 2015-08-20.

*通讯联系人. 电话/传真: (010)62923564; 电子信箱: zpinghao@rcees.ac.cn

基金来源：国家高技术研究发展计划(2012AA063101); 国家自然科学基金(21337003).

本文的英文电子版由Elsevier出版社在ScienceDirect上出版(http://www.sciencedirect.com/science/journal/18722067). 